\title{
Overexpression of Lin28a Aggravates Psoriasis-Like Phenotype by Regulating the Proliferation and Differentiation of Keratinocytes [Corrigendum]
}

\author{
Jang $\mathrm{S}$, Jang $\mathrm{S}$, Kim $\mathrm{SY}$, et al. $J$ Inflamm Res. \\ 2021;14:4299-4312.
}

The authors have advised the author list on page 4299 is incorrect. The correct author list and affiliations are as follows.

$$
\begin{aligned}
& \text { Soyeon Jang }{ }^{I, *} \\
& \text { Soyoung Jang } \\
& \text { Si-Yong Kim ' } \\
& \text { Jiwon Ko' } \\
& \text { Eungyung Kim² } \\
& \text { Ji Yeong Park' } \\
& \text { Hyejin Hyung' } \\
& \text { Jin Hong Lee' }
\end{aligned}
$$

\author{
Su-Geun Lim $^{3}$ \\ Sijun Park ${ }^{3}$ \\ Junkoo $\mathrm{Yi}^{4}$ \\ Heon-Jin Lee ${ }^{5}$ \\ Myoung Ok Kim² \\ Hyun-Shik Lee' \\ Zae Young Ryoo'
}

\begin{abstract}
'School of Life Sciences, BK2I FOUR KNU Creative BioResearch Group, Kyungpook National University, Daegu, Korea; ${ }^{2}$ Department of Animal Science and Biotechnology, Kyungpook National University, Daegu, Korea; ${ }^{3}$ School of Life Sciences, Kyungpook National University, Daegu, Korea; ${ }^{4}$ Gyeongsangbukdo Livestock Research Institute, Yeongju, Korea; ${ }^{5}$ Department of Microbiology and Immunology, School of Dentistry, Kyungpook National University, Daegu, 41940, Korea
\end{abstract}

*These authors contributed equally to this work

\section{Publish your work in this journal}

The Journal of Inflammation Research is an international, peerreviewed open-access journal that welcomes laboratory and clinical findings on the molecular basis, cell biology and pharmacology of inflammation including original research, reviews, symposium reports, hypothesis formation and commentaries on: acute/chronic inflammation; mediators of inflammation; cellular processes; molecular mechanisms; pharmacology and novel anti-inflammatory drugs; clinical conditions involving inflammation. The manuscript management system is completely online and includes a very quick and fair peerreview system. Visit http://www.dovepress.com/testimonials.php to read real quotes from published authors. 